\title{
Joanna Bogotębska*
MIĘDZYNARODOWA KOORDYNACJA POLITYK GOSPODARCZYCH W WARUNKACH KRYZYSU FINANSOWEGO I NIERÓWNOWAG GLOBALNYCH

\begin{abstract}
Streszczenie. Wzrost zainteresowania koordynacją polityk gospodarczych, obserwowany w ostatnich latach, jest konsekwencją niestabilności gospodarki światowej wynikającej z globalnego kryzysu finansowego oraz napięć związanych z nierównowagami globalnymi. Ze względu na negatywne efekty zewnętrzne (spillover), jakie polityka monetarna realizowana na poziomie krajowym generuje w warunkach zglobalizowanej i zintegrowanej gospodarki światowej, szczególnie w okresach dekoniunktury gospodarczej oraz trudności w jednostronnym wdrażaniu polityk dostosowawczych wobec problemu nierównowag globalnych, coraz częściej postulowana jest potrzeba skoordynowanych działań w zakresie polityki gospodarczej, mimo niepewności związanej z ich skutkami oraz trudności z ich uruchomieniem. Znaczenie takich działań w okresie dobrej koniunktury gospodarczej i stabilności finansowej spada, co podkreślają zarówno badania teoretyczne, jak i empiryczne.

Słowa kluczowe: koordynacja polityk gospodarczych, nierównowagi globalne, kryzys finansowy.
\end{abstract}

\section{WPROWADZENIE}

W ostatnich latach nastąpił istotny wzrost zainteresowania międzynarodową koordynacją polityk gospodarczych zarówno na gruncie badań teoretycznych, jak i praktycznych zastosowań tego typu rozwiązań w przezwyciężaniu problemów współczesnej gospodarki globalnej.

Większość dorobku teoretycznego oraz najbardziej znane epizody koordynacji polityk gospodarczych przypadają na lata 70. i 80. XX w. Następne dwie dekady, okres tzw. Great Moderation, to zaniechanie działań w tym obszarze, wynikające z przyjęcia założenia, że polityka fiskalna i monetarna prowadzona na poziomie krajowym, jeśli jest optymalna, pozwala osiągnąć krajowi punkt równowagi i przyczynia się do równowagi w ujęciu globalnym.

Pojawienie się, a także narastanie zjawiska nierównowag globalnych oraz globalnego kryzysu finansowego i wynikającej z niego głębokiej i długookresowej

* Uniwersytet Łódzki, Wydział Ekonomiczno-Socjologiczny, Katedra Międzynarodowych Stosunków Gospodarczych. 
dekoniunktury gospodarczej wyraźnie przyczyniły się jednak do ożywienia rozważań teoretycznych oraz praktycznych zastosowań koordynacji polityk gospodarczych w skali międzynarodowej.

\section{UWARUNKOWANIA, BARIERY ORAZ OBSZARY MIECDZYNARODOWEJ KOORDYNACJI POLITYK GOSPODARCZYCH W RAMACH WIELODEWIZOWEGO SYSTEMU WALUTOWEGO}

Należy zauważyć, że o ile w ramach wielodewizowego systemu walutowego międzynarodowa koordynacja polityk makroekonomicznych stała się zjawiskiem stosunkowo rzadkim w gospodarce światowej, o tyle międzynarodowa kooperacja w innych obszarach ekonomii (takich jak handel, regulacje finansowe) jest zdecydowanie bardziej powszechna i zaawansowana.

Wynika to poniekąd z faktu, że jeszcze na początku lat 80. XX w. badania teoretyczne wskazywały, że korzyści z międzynarodowej koordynacji polityki monetarnej są stosunkowo małe w porównaniu z tymi, jakie można osiągnąć, realizując tę politykę na poziomie krajowym. Dominował pogląd, że jeśli każdy bank centralny w reżimie kursu płynnego będzie prowadził politykę monetarną opartą na przyjętej regule (np. cieszącej się dużym powodzeniem Regule Taylora), optymalną z punktu widzenia stabilności cenowej i makroekonomicznej, nie wystąpią dodatkowe korzyści ze wspólnej polityki realizowanej przez banki centralne, nawet jeśli byłaby ona optymalna. Wyrazem takiego podejścia było akcentowanie niezależności banków centralnych oraz powszechność strategii antyinflacyjnych, w szczególności rosnąca popularność strategii bezpośredniego celu inflacyjnego.

Praktyka polityki gospodarczej podążała za implikacjami teoretycznymi - jak podkreśla J. Taylor, okres Great Moderation charakteryzowało bazowanie banków centralnych w realizacji polityki monetarnej na transparentnej regule. W odniesieniu do pojedynczego kraju tworzyło to sytuację równowagi Nasha, zaś w odniesieniu do międzynarodowego systemu walutowego - punkt „bliski międzynarodowej kooperacyjnej równowagi" (near international cooperative equlibrium - NICE) (Taylor 2013). Nie prowadząc zatem oficjalnie polityki koordynacyjnej, a jedynie opierając krajową politykę monetarną na transparentnej regule, kraje pośrednio przyczyniały się do optymalnej, z punktu widzenia krajowego i globalnego, polityki. Jednocześnie obszarem oficjalnie koordynowanym przez banki centralne stała się sfera regulacyjna (aspekty nadzorcze, ostrożnościowe).

Wśród podstawowych przyczyn słabego zainteresowania krajów koordynacją polityk gospodarczych J. Ostry i A. Ghosh (2013) wymieniają:

1. Asymetrię w wielkości gospodarek (co powoduje, że na poziomie globalnym duża część korzyści z koordynacji może zostać osiągnięta przez kraje, które są zbyt małe, aby uczestniczyły w istotnych porozumieniach międzynarodowych; 
potencjalne korzyści dla krajów dużych są mniejsze - chociaż dzięki większej sile politycznej duże kraje mogą zwiększyć swój udział w potencjalnych korzyściach z koordynacji). Gospodarki systemowo ważne mogą nie być zainteresowane podejmowaniem działań koordynacyjnych z małymi krajami, gdyż nie mają one znaczenia dla ich gospodarek, ale z perspektywy globalnej korzyści odnoszone przez małe kraje mogą być istotne. Prowadzi to do tego, że liczba beneficjentów porozumień koordynacyjnych jest znacznie większa niż liczba ich sygnatariuszy;

2. Nieumiejętność dostrzegania występowania i możliwości realizowania polityki wymienności niektórych celów (trade off) przez decydentów politycznych. Koncentrując się na wąskim zakresie celów polityki gospodarczej, nie uwzględniają ich długookresowych implikacji, nie uwzględniają faktu, że znajomość ich wymienności może sprzyjać wzrostowi dobrobytu;

3. Rozbieżność poglądów i ocen odnośnie sytuacji gospodarczej i transgranicznych efektów transmisji aktualnie realizowanych/perspektywicznych polityk. Najlepszym tego przykładem jest rozbieżność poglądów odnośnie efektów prowadzonej niekonwencjonalnej polityki monetarnej oraz potencjalnych sposobów i skutków korekty nierównowag globalnych w krajach nadwyżkowych i deficytowych.

Podstawowy argument za koordynacją polityk gospodarczych opiera się na spostrzeżeniu, że realizowane na poziomie krajowym mogą generować negatywne efekty zewnętrzne (spillover effects). Literatura empiryczna dotycząca procesów transgranicznej transmisji polityk gospodarczych wskazuje, że na skutek pogłębienia integracji handlowej i finansowej wzrosło działanie mnożników w procesach transmisji, które stanowią obecnie połowę działania mnożników krajowych. Kontrastuje to $\mathrm{z}$ doświadczeniami gospodarki światowej z lat 70. i 80. XX w., kiedy to stanowiły średnio 1/10 mnożników krajowych. Ponadto transmisja polityki fiskalnej dawała wówczas pozytywny efekt za granicą, w przypadku polityki monetarnej skutki były bardziej niejednoznaczne.

Z badań empirycznych wynika wyraźnie, że obecnie efekty transmisyjne są większe w przypadku dużych gospodarek, w przypadku gospodarek silnie ze sobą powiązanych gospodarczo oraz w okresach dekoniunktury gospodarczej. Badania empiryczne MFW wykazują, że działanie mnożników w procesie transmisji polityki fiskalnej USA stanowi 60\% mnożników krajowych. Najsilniej działają one w przypadku Ameryki Łacińskiej i Europy, słabiej w przypadku gospodarek azjatyckich. Wyraźne działanie mnożników w procesach transmisji charakteryzuje również szoki w polityce monetarnej wiodących gospodarek, co jest szczególnie odczuwalne przez kraje, których waluty mają powiązany kurs z USD. Działanie mnożników w transmisji polityki monetarnej stanowi 40\% mnożników krajowych, a największy efekt jest widoczny w przypadku krajów Ameryki Łacińskiej (MFW 2013).

B. Eichengreen (2011) podkreśla, że międzynarodowa koordynacja (lub kooperacja) ma większe szanse powodzenia, jeśli są spełnione następujące uwarunkowania: 
1. Koncentruje się na aspektach technicznych, takich jak linie kredytowe/ swapowe banków centralnych, nadzór ostrożnościowy i regulacje w sektorze finansowym.

2. Przybiera formę zinstytucjonalizowaną.

Skuteczność technicznych obszarów działań koordynacyjnych w formie zinstytucjonalizowanej wynika $\mathrm{z}$ delegowania funkcji koordynacyjnej do grupy ekspertów, wypracowujących wspólne, optymalne stanowisko/kierunek działań, jednocześnie izolując je od nacisków politycznych. Przykładem sprawności takich zinstytucjonalizowanych działań są prace Bazylejskiego Komitetu ds. Nadzoru Bankowego. Trudno jednak sobie wyobrazić utworzenie zinstytucjonalizowanej formuły koordynacji polityk makroekonomicznych ze względu na naturalne dążenie krajów do realizowania niezależnej polityki pieniężnej i fiskalnej. Szczególnie trudne jest międzynarodowe koordynowanie polityki fiskalnej, czego wyrazem są trudności z tworzeniem efektywnego systemu koordynującego krajowe polityki makroekonomiczne w ramach Unii Gospodarczej i Walutowej.

W tym duchu sformułowana jest teoria stabilności opartej na hegemonii (hegemonic stability theory) Kindlebergera, zgodnie z którą koordynacja międzynarodowa jest możliwa tylko wówczas, kiedy jest kierowana przez kraj będący hegemonem, dysponujący siłą monetarną ${ }^{1}$.

3. Jest ukierunkowana bardziej na zachowanie istniejącego kształtu stosowanych polityk, regulacji, reguł postępowania („reżimu polityk”), aniżeli na ich zmienianie i poszukiwanie alternatywnego reżimu. Jak zauważa B. Eichengreen, już P. Kenen wskazuje na konieczność rozróżnienia działań koordynacyjnych na mające na celu zachowanie istniejącego reżimu (regime-preserving cooperation) od tych mających na celu optymalizowanie polityk (policy-optimizing cooperation). Kenen (1990) podkreśla jednocześnie, że historycznie dominująca była pierwsza forma koordynacji, drugą ogranicza trudność osiągania konsensusu.

4. W sferze monetarnej, makroekonomicznej i finansowej jest możliwa pod warunkiem istnienia dobrych, bezkonfliktowych relacji między krajami.

\section{DOŚWIADCZENIA GOSPODARKI ŚWIATOWEJ Z PROCESAMI KOORDYNACJI POLITYK W SYSTEMIE WIELODEWIZOWYM}

W tworzeniu zrębów międzynarodowej koordynacji istotną rolę odegrał system walutowy z Bretton Woods, wychodzący poza epizodyczną koordynację (jaka miała miejsce w latach 20. XX w.) i tworzący zasady postępowania w międzynarodowych stosunkach gospodarczych. Jednakże rola ta przejawiała się bardziej

${ }^{1}$ Brakiem hegemona Kindleberger thumaczy np. długość trwania wielkiego kryzysu gospodarczego z lat 30. XX w., kiedy Wielka Brytania nie sprawowała już tej funkcji, a USA jeszcze jej nie sprawowały. 
w manifestowaniu konieczności powstrzymywania się krajów od polityki beggar-thy-neighbour (poprzez manipulowanie kursem walutowym), aniżeli w angażowaniu się w działania promujące sprawne funkcjonowanie msw.

W ramach systemu wielodewizowego gospodarka światowa ma pewne doświadczenia z procesami koordynacyjnymi, szczególnie wobec zjawiska nierównowag zewnętrznych. Należy tu wspomnieć dwa porozumienia z lat 80 ., wynikające w głównej mierze z kształtowania się kursów walutowych w okresach narastających nierównowag globalnych.

We wrześniu 1985 r., kraje grupy G5 (Francja, Niemcy, USA, Japonia, Wielka Brytania) zawarły tzw. Porozumienie z Plaza, stwierdzając, że istnieją duże nierównowagi zewnętrzne stanowiące potencjalny problem, w szczególności zaś kurs USD odbiega od poziomu kursu równowagi długookresowej. W ramach porozumienia uznano, że kursy walutowe powinny odgrywać wiodącą rolę w procesach dostosowawczych. Banki centralne krajów G5 rozpoczęły skoordynowane interwencje walutowe, mające na celu osłabienie wartości USD. Część Porozumienia z Plaza stanowiło także indywidualne zobowiązanie krajów do prowadzenia określonej polityki wewnętrznej. USA zobowiązały się do ograniczenia deficytu budżetowego, Niemcy - do redukcji podatków. Japonia zobowiązała się do dalszego otwierania rynku wewnętrznego na zagraniczne towary i usługi oraz realizowania polityki stymulującej popyt wewnętrzny, prowadzącej do zwiększenia konsumpcji i inwestycji, m.in. poprzez zwiększanie dostępności kredytów konsumpcyjnych i hipotecznych. W efekcie Porozumienia z Plaza jen uległ aprecjacji w stosunku do USD, zaś nadwyżka płatnicza zaczęła się redukować. Nadwyżka handlowa Japonii z innymi krajami pozostała jednak wysoka, korekta kursowa nie była w stanie jej zredukować, co doprowadziło do zewnętrznych nacisków na ekspansję popytu wewnętrznego. Aprecjacji w stosunku do USD uległa także marka niemiecka, zaś USD ulegał deprecjacji przez cały 1986 r. Zakres, w jakim porozumienie z Plaza przyczyniło się bezpośrednio do deprecjacji USD, pozostaje jednak dyskusyjny.

W tzw. Porozumieniu z Luwru z 1987 r. rządy i banki centralne grupy G7 zgodziły się, że deprecjacja USD jest już zbyt głęboka oraz że kursy walut odzwierciedlają kursy równowagi długookresowej. Porozumienie miało na celu współpracę dla dalszego utrzymywania kursów walutowych wokół bieżących poziomów, co zostało wsparte niepublikowaną umową odnośnie stabilizowania kursów walutowych, utrzymywania USD w 5-procentowym paśmie wahań wobec DEM i jena (Funabashi 1989)². Jednocześnie zaakcentowano rolę dostosowań

2 Porozumienie składało się z ,,pierwszej linii obrony”, polegającej na dobrowolnych interwencjach walutowych jena i marki w paśmie $+/-2,5 \%$ wokół kursów bazowych wobec USD oraz na ustanowieniu ,drugiej linii obrony” (obowiązkowych konsultacjach w celu działań dostosowawczych w sytuacji osiągnięcia pięcioprocentowego odchylenia od ustalonego kursu jena i marki wobec USD). 
makroekonomicznych ${ }^{3}$. Rynki jednak zignorowały porozumienie i trend deprecjacyjny USD zatrzymał się dopiero kilka miesięcy później, kiedy System Rezerwy Federalnej, a w ślad za nim inne banki centralne, podniósł stopy procentowe. Doświadczenie to wykazało, że warunkiem sukcesu koordynacji międzynarodowej jest uznanie jej przez rynki finansowe za wiarygodną.

\section{KOORDYNACJA POLITYK GOSPODARCZYCH W OKRESIE KRYZYSU FINANSOWEGO I GLOBALNEJ DEKONIUNKTURY GOSPODARCZEJ}

W okresie globalnego kryzysu finansowego uaktywnione zostały działania koordynacyjne banków centralnych. Należy tu wymienić skoordynowaną decyzję wiodących banków centralnych z 2008 r. dotyczącą obniżki stóp procentowych. Było to działanie jednorazowe, oceniane jako skuteczny przykład globalnego zarządzania kryzysem gospodarczym. Na poziomie operacyjnym do tego typu działań należy stworzenie sieci porozumień swapowych, mających na celu zapewnienie dostępu do płynności walutowej. Mimo pewnych wad tego typu porozumien (selektywność, niepewność odnośnie czasu trwania i warunków dostępu), powszechnie były one oceniane jako przykład pozytywnej, szybkiej reakcji banków centralnych na zaburzenia w dystrybucji płynności walutowej. Należy jednak przyznać, że podejmując takie skoordynowane działanie, banki centralne nie musiały mierzyć się z problemem wymienności (trade off) z innymi krajowymi celami polityki pieniężnej.

Kolejne działania banków centralnych, borykających się z problemem bliskich zeru nominalnych stóp procentowych oraz długookresowej dekoniunktury gospodarczej, budzą już znacznie więcej kontrowersji. Szerokie stosowanie przez wiodące banki centralne (System Rezerwy Federalnej, Bank Japonii, EBC) polityki quantitative easing (QE) jest krytykowane za generowanie negatywnych efektów spillover i stało się często wysuwanym argumentem za międzynarodową koordynacją polityki monetarnej ${ }^{4}$. Prowadzenie polityki QE, traktowane jako odejście od reguły w polityce monetarnej, tworząc (bezpośrednio i pośrednio) efekty spillover, odczuwane było szczególnie silnie przez kraje emerging markets i prowadziło do konieczności wdrażania przez nie mechanizmów obronnych.

Niewątpliwie polityka QE rozpoczęta przez USA tworzyła łatwiejsze globalne warunki płynnościowe; jednocześnie, poprzez wzrost przepływów kapitału, zwiększała zmienność kursów walutowych, powodowała wzrost kredytu i ryzyko niestabilności finansowej.

${ }^{3}$ Na przykład Japonia miała prowadzić politykę fiskalną i monetarną mającą na celu pobudzenie popytu wewnętrznego, przyczyniającą się do zredukowania nadwyżki zewnętrznej.

${ }_{4}$ Oprócz rządów krajowych instytucją nawołującą do większej koordynacji polityki monetarnej w obliczu negatywnych efektów spillover był szczególnie Bank Rozrachunków Międzynarodowych (BIS) 
Mimo to empiryczne efekty polityki QE nie dają się jednoznacznie ocenić. Niektóre badania wskazują na pozytywne efekty spillover, inne na negatywne; ponadto na różnych etapach stosowania instrumentu efekty działały w różnych kierunkach i odmiennie w zależności od regionu geograficznego. Najbardziej spektakularny negatywny efekt spillover polityki QE amerykańskiego banku centralnego polegał na generowaniu presji na aprecjację walut, tworząc niebezpieczeństwo konkurencyjnych dewaluacji, a nawet, jak w 2010 r. zapowiedział Minister Finansów Brazylii Guido Mantega, „wojen walutowych”.

Wpływ polityki QE amerykańskiego banku centralnego na ceny aktywów i przepływy kapitału nie był już tak oczywisty. Badania empiryczne wykazują, że niektóre epizody polityki łagodzenia ilościowego Systemu Rezerwy Federalnej prowadziły w skali globalnej do redukcji dochodowości obligacji i wzrostu cen akcji, z kolei ilościowe i jakościowe łagodzenie polityki monetarnej stosowane przez Bank Japonii prowadziło do spadku zagranicznych cen aktywów (jak również aprecjacji walut względem jena). Wpływ polityki QE na przepływy kapitałowe również był odmienny na różnych etapach stosowania instrumentu - w początkowym okresie stosowania polityki przez SRF prowadził do odpływu kapitału z krajów emerging markets, następnie do jego masowych napływów, by na etapie rozważania zawężania skali polityki QE ponownie prowadzić do odpływu kapitału (Ostry, Ghosh 2013).

Wpływ polityki QE na zagraniczną produkcję i popyt również nie jest jednoznaczny. Niektóre symulacje wykazują, że polityka ta prowadzi do wzrostu produkcji i popytu, inne wskazują na negatywny wpływ tej polityki na wielkości za granicą. Negatywny wpływ odczuły kraje posiadające bliskie związki handlowe z Japonią na skutek deprecjacji jena i początkowej tendencji spadku cen akcji.

W przypadku krajów emerging markets szczególnie negatywny efekt spillover wyrażał się we wzroście skali napływu kapitału oraz presji na wzrost cen aktywów, co generując presję inflacyjną, utrudniało realizację polityki monetarnej w tych krajach.

Łagodzenie polityki monetarnej pogarszało także równowagę zewnętrzną pozostałych krajów, ale efekt ten był mniejszy w przypadku krajów, które podejmowały działania mające na celu ograniczenie aprecjacji waluty krajowej (Ostry, Ghosh 2013).

$\mathrm{W}$ badaniach empirycznych $\mathrm{z}$ jednej strony akcentuje się zatem negatywne efekty spillover dla zagranicy, z drugiej - pogląd taki wyraził MFW - polityka QE ,pomaga raczej aniżeli szkodzi partnerom handlowym, poprzez wzmacnianie wzrostu, a zatem importu w kraju realizującym taką strategię" (MFW 2011).

Wśród krajów, które deklarowały, że negatywnie odczuwają efekty polityki monetarnej krajów rozwiniętych, były Brazylia, Węgry, Indie, Rosja, ale także inne kraje rozwinięte, takie jak Japonia czy Izrael. Bank Japonii, w obawie przed niekorzystnymi skutkami aprecjacji jena wynikającymi z polityki niskich stóp procentowych i polityki QE amerykańskiego banku centralnego, także rozpoczął 
w 2013 r. programy QE i łagodzenia polityki pieniężnej. Działanie to jest dobrym przykładem, jak polityka monetarna jednego kraju może być determinowana polityką monetarną innego (Taylor 2013). J. Taylor wykazuje wręcz, że odchylenie od reguły w krajowej polityce monetarnej, powodujące przyjęcie podobnej strategii przez inne banki centralne, prowadzi do wzmocnienia efektów spillover.

Ponadto J. Taylor podkreśla, że jako mechanizmy ochronne przed odchyleniem od optymalnej polityki monetarnej zagranicznego banku centralnego (przejawiającej się polityką niskich stóp procentowych oraz QE) krajowy bank centralny może zastosować kontrolę przepływów kapitałowych lub interwencje walutowe. Kontrola przepływów kapitałowych może zahamować presję na aprecjację waluty krajowej oraz pomóc uniknąć ryzykownego zapożyczania. Znaczenie takiego mechanizmu dostrzega też MFW, który w ostatnich latach wyraźnie zliberalizował swoje podejście do tego instrumentu ochrony rynku krajowego.

Innym sposobem przeciwdziałania aprecjacji kursu mogą być interwencje walutowe, zarówno zastosowane jako alternatywa dla obniżania krajowych stóp procentowych w odpowiedzi na ekspansję monetarną zagranicy, jak i komplementarny - w stosunku do niego - instrument. Dla przykładu bank centralny Izraela zastosował, w reakcji na presję aprecjacyjną na walutę krajową, oba instrumenty (obniżkę stóp procentowych oraz interwencje walutowe). Należy zauważyć, że interwencje walutowe jako instrument neutralizowania efektów zagranicznej polityki monetarnej były już stosowane w okresie poprzedzającym kryzys finansowy i przybierały charakter wzmożonych akumulacji rezerw walutowych. Doświadczenia gospodarki światowej z lat poprzedzających wybuch kryzysu, kiedy USA prowadziły ekspansję monetarną, dobitnie wskazują na występowanie sprzężenia zwrotnego w efektach spillover. Nie tylko bowiem skutki polityki monetarnej USA odczuwały kraje emerging markets, przeciwdziałające aprecjacji kursu poprzez akumulację rezerw walutowych, lecz także same USA, doświadczające napływów kapitału wynikającego z polityki akumulacyjnej, co przyczyniało się do utrzymywania niskich długoterminowych stóp procentowych, finansowania rynku kredytów hipotecznych oraz tworzenia niestabilności prowadzącej ostatecznie do kryzysu finansowego. Zjawisko to obrazuje akcentowany w literaturze teoretycznej i empirycznej wzrost znaczenia przepływów kapitałowych brutto w stosunku do przepływów netto, co na skutek występowania sprzężenia zwrotnego efektów spillover może stanowić zasadniczy argument za międzynarodową koordynacją polityki monetarnej.

Alternatywny pogląd odnośnie kształtu polityki pieniężnej w warunkach kryzysowych wyraża B. Bernake (2013). Twierdzi, że obserwowana strategia naśladowania zachowań banków centralnych (wynikająca zasadniczo z obaw o kształtowanie się kursu walutowego), przybierająca formę obniżania stóp procentowych albo wdrażania QE, już jest swego rodzaju międzynarodową koordynacją polityki monetarnej, którą nazywa „wspólnym łagodzeniem monetarnym” (joint monetary easing), wynikającą nie z reakcji na politykę innego kraju, lecz na powstały global- 
ny szok. Jednocześnie porównuje obecną sytuację do okresu wielkiego kryzysu gospodarczego z lat 30. XX w., w trakcie którego poszczególne kraje opuszczały standard złota, stosując politykę łagodzenia monetarnego w postaci konkurencyjnych dewaluacji, a więc wdrażały identyczne mechanizmy w odpowiedzi na wspólny szok, nie tworząc przy tym formalnego mechanizmu koordynacyjnego. B. Bernake (2013) zwraca także uwagę, że stosowana polityka joint monetary easing, mająca na celu wzmocnienie krajowego wzrostu gospodarczego, w przypadku krajów rozwiniętych tworzy pozytywne efekty spillover dla partnerów handlowych, nie można jej więc traktować jako polityki zubożania sąsiada (beggar-thy-neighbour); bliższa jest raczej polityce wzbogacania sąsiada (enrich-thy-neighbor). Stwierdzenie to jednak nie dotyczy w pełni krajów emerging markets i rozwijających się, w przypadku których efekt kursowy (aprecjacja kursu partnera handlowego) dominuje nad pozytywnym efektem silniejszego wzrostu wynikającego ze wzrostu popytu; dodatkowo słabo rozwinięty system finansowy rodzi obawy o powstawanie nierównowag finansowych. Potwierdzają to doświadczenia krajów emerging markets z Azji i Ameryki Łacińskiej, wyrażających obawy o efekty polityki QE.

J. Taylor wskazuje, że nie można takiego globalnego trendu łagodzenia polityki monetarnej traktować jako niezbędnego środka wychodzenia z kryzysu, naturalnej globalnej reakcji na globalny szok. Argumentuje, że w przeciwieństwie do okresu wielkiego kryzysu gospodarczego, niekoniecznie takie globalne łagodzenie było zasadne - kraje emerging markets i rozwijające się szybko wyszły z kryzysu i - przynajmniej w niektórych przypadkach - bardziej istotne było przeciwdziałanie naciskom inflacyjnym i boomom na rynkach surowcowych w postaci wyższych stóp procentowych. Działania takie hamowałyby obawy przed ryzykiem napływów kapitału wynikających z dysparytetu stóp procentowych.

W ocenie polityki monetarnej w zarządzaniu kryzysowym uderzający jest zatem brak jednoznacznego (zarówno na gruncie teoretycznym, jak i empirycznym) postrzegania efektów spillover polityki QE. Wynika to z braku dokładnej znajomości mechanizmów transmisyjnych polityki QE zarówno dla gospodarki krajowej, jak i zagranicy. Akcentowane przez J. Taylora dwa efekty transmisji polityki QE (efekt kursowy i popytowy, których wzajemne znoszenie się - jak wskazano - inaczej przebiegało w odniesieniu do krajów rozwiniętych, jak Japonia, inaczej w odniesieniu do krajów emerging markets) zakładają występowanie wysokiego stopnia integracji międzynarodowych rynków kapitałowych i towarowych. Tymczasem Obstfeld i Rogoff (2002) wskazują, że występowanie zaburzeń w funkcjonowaniu międzynarodowych rynków kapitałowych tworzy większe uzasadnienie dla międzynarodowej koordynacji polityki monetarnej. Wynika to z tego, że im mniej podmiotów operujących na rynkach kapitałowych może zdywersyfikować ryzyko w skali międzynarodowej, tym większa potrzeba koordynacji.

J. Sachs i W. McKibbin (1985) w swoich badaniach empirycznych wykazali, że koordynacja polityki monetarnej wiodących gospodarek (których polityka dezinflacyjna była nadmiernie restrykcyjna) w okresie przed wybuchem kryzysu 
zadłużeniowego w Ameryce Łacińskiej (na początku lat 80.) pomogłaby, na skutek niższych światowych stóp procentowych, krajom wysoce zadłużonym. Prowadzi to do konkluzji, że to, czy kraje trzecie korzystają czy tracą z koordynacji polityki monetarnej, zależy od ich specyfiki i konkretnych uwarunkowań (Sachs, McKibbin 1985). Potwierdza też tezę, że na podejmowaniu działań koordynacyjnych mogą skorzystać małe kraje.

W porównaniu do polityki monetarnej kwestia koordynacji polityki fiskalnej przyciągała mniej uwagi. Większość krajów zastosowała się do wytycznych uzgodnionych w ramach G20 z 2009 r. i wprowadziła ekspansję fiskalną jako element zarządzania kryzysowego.

K. Rogoff zwraca jednocześnie uwagę, że istotne jest zapewnienie długookresowej stabilności polityki fiskalnej, która ograniczyłaby zarówno oczekiwania inflacyjne, jak i premię za ryzyko stopy procentowej. Tworzy to przestrzeń dla większej koordynacji polityki fiskalnej na obecnym etapie wychodzenia gospodarki światowej z recesji (Taylor 2013).

\section{KOORDYNACJA POLITYK GOSPODARCZYCH WOBEC ZJAWISKA NIERÓWNOWAG GLOBALNYCH}

Zjawisko nierównowag globalnych powoduje, że kraje nadwyżkowe i deficytowe stoją przed innymi źródłami zniekształceń i zagrożeń, odmienna jest rola poszczególnych polityk makroekonomicznych w osiąganiu stanu równowagi. Niemożliwość wymuszenia działań dostosowawczych na krajach generujących nierównowagi, a także nieskuteczność mechanizmów automatycznego przywracania równowagi oraz coraz częściej wskazywana wadliwość systemowa międzynarodowego systemu walutowego ${ }^{5}$ powodują, że coraz więcej uwagi przyciągały możliwości koordynowania działań w celu niedopuszczenia do scenariusza gwałtownej korekty nierównowagi globalnej (disruptive/disorderly adjustment). Kontynuacja polityk gospodarczych po stronie krajów nadwyżkowych i deficytowych utrudnia każdemu z nich podjęcie decyzji o jednostronnym dostosowaniu. Ponadto, jak zauważa F. Saccomanni (2008), rynki wiarygodniej oceniają takie działania (np. w zakresie stabilizowania kursów walutowych) niż działania jednostronne.

Wobec napięć wynikających z nierównowag globalnych najwięcej uwagi przyciąga możliwość i zakres niezbędnych dostosowań kursowych. Koordynacja

5 Jej przykładem są trudności z utworzeniem mechanizmu przełamującego asymetrię w ponoszeniu ciężaru dostosowawczego nierównowag globalnych. Trudności te były widoczne m.in. w nieskuteczności tzw. klauzuli waluty deficytowej wdrożonej w ramach zarządzania systemem walutowym z BrettonWoods. W międzynarodowej koordynacji coraz częściej upatruje się szansę na stworzenie bardziej symetrycznego międzynarodowego systemu walutowego, który zapewniałby bardziej symetryczną dystrybucję ciężaru dostosowawczego między krajami deficytowymi a nadwyżkowymi (zob. Bogołębska 2013). 
nie oznacza tu jednak stabilizacji kursów walutowych, która jest optymalna jedynie w sytuacji, gdy kraje są dotknięte wspólnym szokiem. Takie czynniki, jak międzynarodowa pozycja inwestycyjna lub różnice w produkcji mogą tworzyć asymetrie, przez co stabilizacja kursowa staje się nieoptymalna (Obstfeld, Rogoff 2002).

W zarządzaniu nierównowagami globalnymi - zarówno w procesach negocjacyjnych, jak i decyzyjnych - przyciąga uwagę dominująca rola niesformalizowanych ugrupowań międzynarodowych (G7, G20). Próby skoordynowanego podejścia do problemu nierównowag globalnych, odnotowywane od 2003 r., wskazują na trudności z realizacją koordynacji polityk gospodarczych. Należy tu wymienić dwa obszary działań koordynacyjnych:

1. Wielostronne konsultacje w sprawie nierównowag globalnych, uruchomione na początku XXI w. jako narzędzie wielostronnego nadzoru mającego na celu monitorowanie narastania lub rozwiązanie problemu nierównowag globalnych przy zapewnieniu wysokiego wzrostu globalnego. Mimo że w toku konsultacji ustalono niezbędne obszary dostosowań zarówno ze strony krajów nadwyżkowych, jak i deficytowych, ich implementacja nie przebiegała zgodnie z uzgodnieniami. Jak wskazują Ostry i Ghosh (2013), zamiast wdrażania polityk uzgodnionych w toku konsultacji następowało obwinianie (,blame game”) uczestników gospodarki światowej o to, kto odpowiada za nierównowagi globalne. Ostatecznie globalny kryzys finansowy odwrócił uwagę międzynarodowych decydentów od spraw nierównowag i spowodował czasowe zejście problemu na drugi plan.

2. Utworzenie, z inicjatywy krajów G20, procedury wzajemnego oceniania polityk (tzw. Mutual Assessment Policies, MAP), pod nadzorem technicznym MFW. MAP opiera się na formułowaniu wspólnego celu i angażowaniu się krajów członkowskich w dynamiczny proces analizy wskaźników makroekonomicznych i dokonywaniu niezbędnych dostosowań pozwalających osiągnąć wyznaczony cel. Jak na razie nie obserwuje się $\mathrm{w}$ gospodarkach systemowo ważnych wdrażania polityk dostosowawczych, rekomendowanych w ramach MAP (Faruqee, Srinivasan 2012).

Mimo słabego przełożenia na sferę realizacyjną działania te stanowią pierwszą (od Porozumień z Plaza i Luwru) próbę multilateralnego rozwiązywania problemów gospodarki globalnej na drodze działań koordynacyjnych.

\section{WYZWANIA DLA KOORDYNACJI POLITYK GOSPODARCZYCH KOORDYNACJA CZY KOOPERACJA?}

Nierównowagi globalne oraz głęboka dekoniunktura gospodarcza wywołana kryzysem finansowym spowodowały wzrost świadomości konieczności działań koordynacyjnych w skali międzynarodowej. Jest to zgodne z przewidywaniami teoretycznymi L. Pauly, który w latach 90. XX w. wskazywał, że działania te dynamizuje wspólna percepcja kryzysu zagrażającego istniejącemu 
reżimowi (regime-threatening crisis). Dodatkowo istnieje coraz większy konsensus, że w procesach korekty nierównowagi globalnej bardziej efektywne dla gospodarki światowej jako całości może być podejście skoordynowane (coordinated approach) od podejścia indywidualnego (competitive approach), rodzącego niebezpieczeństwo konkurencyjnych działań dyskryminacyjnych (np. protekcjonizmu, reglamentacji dewizowej).

Jak wskazuje teoria i praktyka międzynarodowej koordynacji polityk gospodarczych, jej zasadność i znaczenie wzrasta w fazie kryzysu. W czasach dobrej koniunktury i stabilności na rynkach finansowych jej znaczenie staje się sprawą drugoplanową. Ponadto obserwujemy wzrost świadomości, że działania koordynacyjne powinny wyjść poza obszary techniczne i dotyczyć polityki makroekonomicznej, w szczególności monetarnej. Nie ma jednak wystarczająco spójnego stanowiska dotyczącego efektów koordynacji polityki monetarnej w okresach dobrej koniunktury. Niektóre badania estymują, że korzyści te są małe (porównywalne do tych z liberalizacji handlu), inne, uwzględniające współoddziaływanie czynników finansowych - że większe. W trakcie ostatnich dwóch dekad przepływy kapitału dłużnego do krajów emerging markets były wyższe w okresach, kiedy kraje rozwinięte miały niskie i o małej zmienności stopy procentowe (,, łatwe warunki finansowe") niż w okresach, kiedy były one wysokie (Bayoumi i in. 2014).

Jeanne (2013) stoi na stanowisku, że koordynacja polityki monetarnej może nie być konieczna, jeśli występuje koordynacja polityki makroostrożnościowej i zarządzania rachunkiem kapitałowym, co wynika $\mathrm{z}$ uznania ich za podstawowe narzędzia radzenia sobie z efektami zewnętrznymi (externalities) wynikającymi z napływów kapitału.

Dlatego też, jak rekomenduje J. Taylor, optymalnym rozwiązaniem na przyszłość jest powrót krajów do realizowania polityki monetarnej opartej na regule, co pozwoliłoby odtworzyć stan bliskiej równowagi. Jak wskazały doświadczenia z zarządzaniem ostatnim kryzysem finansowym, koordynowane łagodzenie polityki monetarnej może dla niektórych krajów rodzić silne efekty negatywne. Doświadczenia te wskazują, że w przypadku krajów, które nigdy nie doświadczały boomów na rynkach aktywów, ale są silnie wyeksponowane na globalne cykle kredytowe i płynnościowe, wspólna ponadnarodowa polityka monetarna może nie być optymalną.

Na obecnym etapie gospodarki światowej kluczowymi problemami z zakresu polityki makroekonomicznej stają się następujące: jak wyjść z polityki QE, jak znaleźć równowagę między celem krótkookresowego stymulowania fiskalnego a krótko- i długookresową konsolidacją fiskalną, nie tworzyć sytuacji „wojen walutowych", ograniczyć nierównowagi globalne przy jednoczesnym ożywianiu gospodarki. Dlatego też w fazie przezwyciężania napięć związanych z wychodzeniem z kryzysu i nierównowagami globalnymi wskazuje się na potrzebę zwiększenia koordynacji polityk gospodarczych. Wobec niepewności efektów Ostry i Ghosh (2013) proponują dwa rozwiązania służące zwiększeniu stopnia międzynarodowej koordynacji polityk gospodarczych: 
1. Ustanowienie neutralnego asesora (neutral assessor), który godziłby rozbieżne poglądy krajowych decydentów. Jego rola polegałaby nie na proponowaniu kierunków prowadzenia polityk gospodarczych, lecz na prezentowaniu analiz alternatywnych strategii i wiążących się z nimi efektów dla innych celów (trade offs) oraz spodziewanych efektów spillover. Pozwoliłoby to poszczególnym krajom lub grupom krajów wypracować najlepsze rozwiązania. Warunkiem sprawności takiego rozwiązania jest akceptacja neutralności i wiarygodności asesora przez wszystkie strony.

Jak zauważają Ostry i Ghosh (2013), koncepcja neutralnego asesora przedstawiającego obiektywne analizy nie jest nowa. Na mniejszą skalę takie rozwiązanie próbowała wdrożyć Grupa Robocza ds. Interwencji Walutowych (Jurgenesen Report) na Szczycie Ekonomicznym w Wersalu w 1982 r., w celu oszacowania efektywności sterylizowanych interwencji walutowych. Koncepcja ta opierała się na założeniu, że efekty analiz Grupy Roboczej są bardziej obiektywne. W analizach asesor wykorzystywałby rezultaty nadzoru dwustronnego.

2. Ustanowienie wytycznych (guideposts), które ograniczałyby negatywne efekty spillover poprzez rachunek bieżący i kapitałowy. Rozwiązanie to polegałoby na ustanowieniu dwóch obszarów wytycznych.

Pierwszy miałby na celu ochronę przed niedopasowaniami kursowymi i nierównowagami zewnętrznymi. Do oceny, czy niedopasowanie kursowe i poziom nierównowagi zewnętrznej jest zgodny z wytycznymi wykorzystywano by opracowywane przez MFW w ramach jego polityki nadzoru (surveillence) External Balance Assessment/External Stability Report. Wytyczne zobowiązywałyby kraje do reagowania na odchylenia w politykach gospodarczych prowadzące do istotnych zniekształceń (monetarnej, kursowej, fiskalnej, reform strukturalnych, które mogą wpływać na popyt w sektorach tradables i nontradables). Realizacja tego celu opierałaby się na obecnych praktykach dwustronnego i wielostronnego nadzoru w ramach MFW.

Drugi koncentrowałby się na przepływach finansowych. Miałby na celu przeciwdziałanie eksportowaniu ryzyka niestabilności finansowej w skali międzynarodowej, koncentrowałby się zatem na politykach (np. ekspansywna polityka monetarna, słabe regulacje ostrożnościowe), które mogłyby generować efekty spillover w tym obszarze. Ustanawianie wytycznych w tym obszarze opierałoby się na istniejących analitycznych/empirycznych metodach oceny ryzyka kredytowego/ boomów na rynku aktywów/cykli na rynkach finansowych oraz ryzyka ich międzynarodowej transmisji. W sytuacji pojawienia się takiego ryzyka w pierwszej kolejności działania na rynku krajowym powinien podjąć kraj generujący ryzyko niestabilności/kryzysu, ale co istotne, powinna w tym obszarze być wzmocniona zasada wzajemności (np. kraj zagrożony transmisją ryzyka niestabilności finansowej także powinien podjąć działania, np. poprzez kontrolę napływu kapitału).

Oba powyższe rozwiązania opierają się na już wypracowanych w ramach MFW procesach. Wprowadzony niedawno dla członków MFW tzw. Integrated 
Surveillance Decision obliguje kraje realizujące wewnętrzne cele polityki gospodarczej do takiego jej kształtu, aby osiągając krajowe cele, minimalizowały negatywne efekty spillover. Bazując na Integrated Surveillance Decision, koncepcja wytycznych wymuszałaby na krajach odrzucenie polityk generujących negatywne efekty spillover (kanałami przepływów finansowych i towarowych), nawet gdyby wystąpił pewien koszt na poziomie krajowym.

\section{BIBLIOGRAFIA}

Bayoumi T., Dell'Ariccia G., Habermeier K., Mancini-Griffoli T., Valencia F. (2014), Monetary policy in the new normal, „IMF Staff Discussion Note”, April, SDN 14/3.

Bernake B. (2013), Monetary policy and the global economy, London School of Economics, 25 March.

Bogołębska J. (2013), Nierównowagi globalne a stabilność międzynarodowego systemu walutowego. Analiza na przyktadzie akumulacji rezerw walutowych, Wydawnictwo Uniwersytetu Łódzkiego, Łódź.

Eichengreen B. (2011), International policy coordination: the long view, „National Bureau of Economic Research Working Paper Series", No. 17665.

Faruqee H., Srinivasan K. (2012), The G20 Mutual Assessment Process- a perspective from IMF Staff, „Oxford Review of Economic Policy”, Vol. 28, No. 3.

Funabashi Y. (1989), Managing the dollar: from the Plaza to the Louvre, „Institute for International Economics", Vol. 26, Issues 3-4.

Jeanne O. (2013), Macroprudential policies in global perspective, John Hopkins University, Paper prepared for the 2013 Asia Economic Policy Conference, Federal Reserve Bank of San Francisco, No. 3-5.

Kenen P. (1990), The international coordination of policies, [w:] W. Branson, J. Frenkel, M. Goldstein, International policy coordination and exchange rate fluctuations, University of Chicago Press, National Bureau of Economic Research Conference Report.

MFW (2011), The United States: Spillover Report - 2011 Article IV Consultation.

MFW (2013), Dancing together? Spillovers, common shocks, and the role of financial and trade linkages, Chapter 3, World Economic Outlook, October.

Obstfeld M., Rogoff K. (2002), Global implications of self-oriented national monetary rules, „Quarterly Journal of Economics", Vol. 117, No. 2.

Ostry J., Ghosh A. (2013), Obstacles to international policy coordination, and how to overcome them, „IMF Staff Discussion Note”, December.

Pauly L. (1993), From monetary manager to crisis manager: systemic change and the International Monetary Fund, [w:] R. Morgan, New Diplomacy un the post-cold war Word, Palgrave Macmillan.

Saccomanni F. (2008), Managing international financial instability. National tamers versus global tigers, E. Elgar, Cheltenham UK, Northampton MA.

Sachs J., McKibbin W. (1985), Macroeconomic policies in the OECD and LDC external adjustment, „NBER Working Paper”, No. 1534.

Taylor J. (2013), International monetary policy coordination: past, present and future, „BIS Working Papers", No. 437, December. 


\title{
Joanna Bogołębska
}

\section{INTERNATIONAL COORDINATION OF MACROECONOMIC POLICIES IN FACE OF FINANCIAL CRISIS AND GLOBAL IMBALANCES}

\begin{abstract}
Increased interest in coordination of macroeconomic policies, which is due to both the instability of the global economy as the consequence of financial crisis and the phenomenon of global imbalances, has been observed during last years. The main arguments for coordinated actions are: negative spillover effects of monetary policy implemented unilateral in globalised and integrated global economy, especially in times of economic downturns and difficulties in adoption of adjustment policies unilaterally. However, both the uncertainty about the effects and difficulties with implementation are the main brakes for coordinated actions. Both theoretical and empirical studies on international coordination of macroeconomic policies stress that the significance of it falls in times of stability and economic booms.
\end{abstract}

Keywords: international coordination of economic policies, global imbalances, financial crisis. 